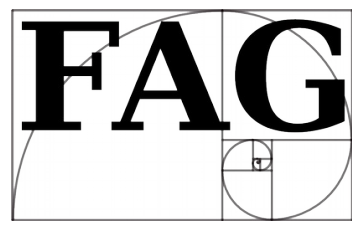

Filozoficzne Aspekty Genezy - 2014, t. 11

Philosophical Aspects of Origin

s. $153-160$

http://www.nauka-a-religia.uz.zgora.pl/images/FAG/2014.t.11/art.10.pdf

\author{
Yi Zheng i Gonzalo Munévar
}

\title{
Jaźń w perspektywie biologicznej *
}

$W$ Pamięci absolutnej ${ }^{* *}$ bohater odkrywa, że jego jaźn dobrego faceta to tylko wszczepione wspomnienia. Jego ciało byto kiedyś zajmowane przez inna, bezwzględna jaźń, której powrotu chca jego sprzymierzeńcy. Tę fantastyke uwiarygodnia nieco tradycyjna koncepcja jaźni jako kolekcji doświadczeń przechowywanych w pamięci - cechującej się jednościa, świadomej jaźni, dzięki której odczuwamy nasze doświadczenia jako własne. Świetna fantastyka naukowa, kiepska neuronauka. W mózgu nie istnieje żadna centralna struktura, która odpowiadałaby takiej jaźni, a niektórzy naukowcy doszli do wniosku, że jaźń

*Yi Zheng and Gonzalo MunÉvar, „Understanding the Self Biologically”, Brain-Mind Magazine 2013, vol. 2, no. 1, s. 1-3, http://www.brain-mind-magazine.org/read.php?file=BMM-V2-N1a1-SelfBiology-a.pdf (02.05.2015). Za zgodą Autorów i Redakcji z języka angielskiego przełożył: Radosław Plato.

** (Przyp. thum.) Autorzy mają na myśli film science fiction Pamięć absolutna (ang. Total Recall) z Arnoldem Schwarzeneggerem i Sharon Stone z 1990 roku (w roku 2012 nakręcono znacznie gorszy od oryginału - remake tego filmu z Colinem Farrellem i Kate Beckinsale), powstały na kanwie wielokrotnie przedrukowywanego opowiadania Philipa K. Dicka „We Can Remember It for You Wholesale”. Por. np. Philip K. Dick, „We Can Remember It for You Wholesale", w: Philip K. Dick, The Collected Short Stories of Philip K. Dick, Vol. 2: We Can Remember It for You Wholesale, Carol Publishing Group, New York, 1990, s. 35-52. Przekład polski: Philip K. Dıck, „Przypomnimy to panu hurtowo”, w: Philip K. Dıск, Przypomnimy to panu hurtowo. Opowiadania zebrane, t. 2, przeł. Magdalena Gawlik, Nowa Fantastyka, Prószyński i S-ka, Warszawa 1998, s. 43-63. Wydanie drugie ukazało się pod zmienionym tytułem: por. Philip K. Dıск, Impostor - test na czlowieczeństwo, przeł. Magdalena Gawlik, Fantastyka, Prószyński i S-ka, Warszawa 2002.

Na podstawie scenariusza Piers Anthony, pisarz science fiction i fantasy, napisał powieść pt. Total Recall. Por. Piers Anthony, Total Recall, William Morrow \& Co., New York 1989. Przekład polski: Piers Anthony, Pamięć absolutna, przeł. Andrzej Kaniewski, Atlantis, Warszawa 1990. 
jest iluzją. Poglad, że jaźń oznakowuje nasze doświadczenia jako nasze własne, wydaje się błędny. A idea, że jaźn to kolekcja zapamiętanych doświadczeń, okazuje sie fatszywa. W zamian przedstawiamy rewolucyjna biologiczna koncepcje jaźni: mózg ewoluowat tak, aby utworzyć jaźń, która przeważnie jest nieświadoma i rozproszona. Nasza koncepcja likwiduje paradoksy, wyjaśnia wszystkie na pozór sprzeczne wyniki eksperymentów i otwiera nowe możliwości badawcze w neuronaukach.

W ciągu ostatnich trzydziestu lat neuronauki przeszły radykalną przemianę, częściowo dzięki dostępności nowych technik obrazowania mózgu. Pytania o umysł, które, jak się zdawało, stanowiły domenę filozofii, obecnie stoją otworem przed badaniami eksperymentalnymi. Ponieważ zrozumienie jaźni miałoby bezsporną wartość, nie jest zaskakujące, że nowa nauka próbowała odkryć biologiczne odpowiedniki ustaleń uzyskanych po setkach lat introspekcji. Lecz gdy naukowcy usiłowali zrobić z tych ustaleń dobry użytek, dochodzili do paradoksalnych albo sprzecznych wyników. Moglibyśmy bezradnie rozłożyć ręce i oznajmić, że zrozumienie jaźni znajduje się poza zasięgiem nauki. ${ }^{1} \mathrm{~W}$ niniejszym artykule proponujemy owocniejsze rozwiązanie: skoro neuronauki zajmują się mózgiem, powinniśmy dysponować pojęciem jaźni opartym na biologii. Jeśli będziemy je mieli, paradoksy znikną, a wyniki eksperymentów nabiorą sensu.

Aby dostrzec trudności, jakimi obarczona jest tradycyjna koncepcja jaźni, rozważmy trzy spośród najbardziej podstawowych i z pozoru oczywistych ustaleń, które jej towarzyszą: (1) każdy z nas postrzega siebie jako jednostkę, a stąd wnioskujemy, że jaźń jest obiektem scentralizowanym; (2) sądzimy również, iż jaźń jest świadoma tego, że nasze doświadczenia są faktycznie nasze, a tym samym przyjmujemy, iż jaźń oznakowuje je jako nasze, że pełni ona rolę czynnika nadzorującego; (3) intuicyjnie wyczuwamy, że każdego z nas konstytuuje zbiór własnych doświadczeń (kolekcja ta jest przechowywana w formie tego, co psychologowie nazywają ,wspomnieniami epizodycznymi”). Na przykład w odniesieniu do ustalenia (2) psychologowie rozwojowi wskazują, że jaźń dziecka wyłania się, gdy uczy się ono odróżniać swoje doświadczenia od tych, które należą

\footnotetext{
${ }^{1}$ Por. Stanley B. KLeIn, „The Self and Science: Is It Time for a New Approach to the Study of Human Experience?”, Current Directions in Psychological Science 2012, vol. 21, no. 4, s. 253 [253-257].
} 
do innych. Co do ustalenia (3) zdawałoby się, że jeśli zastąpilibyśmy wspomnienia epizodyczne jakiegoś człowieka innym zbiorem wspomnień, to stałby się inną osobą: dalibyśmy mu inną jaźń. Na tym właśnie polega główny motyw fabularny (plot device) w filmie Pamięć absolutna: bohater, naprawdę porządny gość, dowiaduje się, że jego wspomnienia epizodyczne zostały mu wszczepione. Kiedyś był złoczyńcą, dopóki jego wspomnienia epizodyczne nie zostały podmienione na fałszywe. A teraz sprzymierzeńcy szwarccharakteru chcą umieścić z powrotem jego starą, złą jaźń w jego ciele poprzez wszczepienie na nowo starych wspomnień epizodycznych.

Ta tradycyjna koncepcja zapewnia dobrą fabułę, ale prowadzi do złej nauki. Problem z ustaleniem (1) polega na tym, że nie ma w mózgu żadnej struktury, która odpowiadałaby jakiemuś scentralizowanemu obiektowi. W badaniach polegających na obrazowaniu mózgu, w których eksperymentatorzy proszą uczestników o przypisanie cech osobowości (na przykład życzliwości) sobie lub innym, największa aktywność mózgu w trakcie przypisywania cech sobie samym zdaje się zachodzić w obszarze zwanym przyśrodkową korą przedczołową [medial prefrontal cortex]. ${ }^{2}$ Ale ten sam obszar nie wydaje się już tak ważny, gdy zadanie polega na odróżnianiu zdjęć własnej osoby od zdjęć innych. ${ }^{3}$ Im więcej rodzajów pytań, tym więcej rodzajów odpowiedzi, a zatem można zastanawiać się, czy neuronaukowe badania nad jaźnią pogrążają się w chaosie lub nawet czy w ogóle istnieje coś takiego, jak , ,jaźń”.

Poza tym introspekcyjna filozofia ma tendencję do brania jaźni i poczucia jaźni za to samo („Myślę, więc jestem”, rzekł Kartezjusz). Doświadczenie daje nam rzekomo bezpośredni dostęp do własności, jakie ma jaźń. Dla słynnego neuronaukowca z New York University, Rodolfo Llinása, oznacza to, że poczucie jaźni (a tym samym jaźń) stanowi formę percepcji wewnętrznej. ${ }^{4}$ Lecz neu-

\footnotetext{
${ }^{2}$ Por. C. Neil Macrae, Todd F. Heatherton, and William M. Kelley, „A Self Less Ordinary: The Medial Prefrontal Cortex and You”, w: Michael S. Gazzaniga (ed.), The Cognitive Neurosciences III, A Bradford Book, MIT Press, Cambridge, Massachusetts — London 2004, s. 10671075.

${ }^{3}$ Por. David J. Turk, Todd F. Heatherton, William M. Kelley, Margaret G. Funnell, Michael S. Gazzaniga, and C. Neil Macrae, „Mike Or Me? Self-recognition in a Split-Brain Patient”, Nature Neuroscience 2002, vol. 5, no. 9, s. 841-842.

${ }^{4}$ Por. Rodolfo R. LlinÁs, Ja z wiru. Od neuronów do selfu, przeł. Jan J. Trąbka i Piotr
} 
ronaukowe badania percepcji wykazały, że percepcja jest „iluzją” (albo konstrukcją) utworzoną przez mózg. A skoro w mózgu nie ma żadnego centralnego lub centralizującego obszaru, to Llinás dochodzi do wniosku, że jaźń jest jedynie iluzją!

Podczas gdy ustalenie (1) zdaje się prowadzić do paradoksu, pozostałe dwa zostały po prostu obalone przez badania eksperymentalne. Ustalenie (2) staje się wątpliwe nawet na poziomie doświadczenia introspekcyjnego. Kiedy jesteśmy pochłonięci intensywnym doświadczeniem percepcyjnym, takim jak słuchanie pięknej muzyki, mamy po prostu to doświadczenie, ale nie towarzyszą mu żadne znaczniki, że jest ono nasze. Francis Crick i Christof Koch próbowali uratować „nadzorującą” funkcję jaźni, wskazując, że oznaczanie może być przeprowadzane nieświadomie, najprawdopodobniej przez obszary czołowe w mózgu. ${ }^{5}$ Jednak Ilan Goldberg wraz z kolegami wykazali, że podczas wykonywania wymagających zadań percepcyjnych pobudzenie płata czołowego [frontal lobe] w rzeczywistości maleje. ${ }^{6}$ Co się tyczy ustalenia (3), które stanowiło podstawę fabuły Pamięci absolutnej, Stanley Klein dowiódł, że pacjenci, którzy są całkowicie niezdolni do kształtowania nowych wspomnień epizodycznych (ponieważ ich hipokampy nie funkcjonują), mimo wszystko mogą w sporym stopniu rozumieć swoją własną osobowość. ${ }^{7}$ Jaźń musi być konstytuowana przez coś innego niż wspomnienia epizodyczne! A czarny charakter, nawet z wszczepionymi nowymi wspomnieniami, nadal pozostałby złoczyńcą.

K. Walecki, [b.w.], Kraków 2008.

(Przyp. tłum.) W znacznie lepszym przekładzie na język polski ukazał się także rozdział 6 (s. 111-131) wspomnianej pracy w postaci artykułu pt. „Ja z wiru”. Por. Rodolfo R. Llinás, „Ja z wiru”, przeł. Anna Binder i Marek Binder, w: Andrzej Klawiter (red.), Formy aktywności umysłu. Ujęcia kognitywistyczne. Tom 1. Emocje, percepcja, świadomość, Nowe Tendencje w Psychologii, t. 13, Wydawnictwo Naukowe PWN, Warszawa 2008, s. 364-384.

${ }^{5}$ Por. Francis Crick i Christof Koch, „Rama teoretyczna dla świadomości”, przeł. Anna Binder i Marek Binder, w: KLAwiter (red.), Formy aktywności umysłu..., s. 302-323.

${ }^{6}$ Por. Ilan I. Goldberg, Michal Harel, and Rafael Malach, „When the Brain Loses Its Self: Prefrontal Inactivation during Sensorimotor Processing”, Neuron 2006, vol. 50, no. 2, s. 329-339, doi: 10.1016/j.neuron.2006.03.015.

${ }^{7}$ Por. Stanley B. KLein, „The Cognitive Neuroscience of Knowing One's Self”, w: Michael S. Gazzaniga (ed.), The Cognitive Neurosciences III, A Bradford Book, MIT Press, Cambridge, Massachusetts - London 2004, s. 1077-1089. 
Z perspektywy biologicznej sprawy mają się zupełnie inaczej. Biorąc pod uwagę teorię ewolucji, zdajemy sobie sprawę, że każdy mózg z prawdziwego zdarzenia posiada funkcję analizowania informacji zewnętrznej przy jednoczesnym uwzględnianiu informacji o wewnętrznych stanach organizmu w kontekście jego historii osobistej i genetycznej. ${ }^{8}$ To pełnienie tych funkcji pozwala organizmowi z większym powodzeniem oddziaływać z jego środowiskiem fizycznym i społecznym $i$ jednocześnie umożliwia odróżnianie siebie od innych jednostek. A to są właśnie te cechy charakterystyczne, których wymagalibyśmy od jaźni. Przyjmując coś takiego jako biologiczną koncepcję jaźni, spostrzeżemy, że wyniki eksperymentów są z nią zgodne. Po pierwsze, powinniśmy oczekiwać, że istnieje wiele sposobów, w jakie mózg musi odróżniać swój organizm od innych, to jest: próby odróżniania jaźni będą wymagały wielkiej liczby różnorodnych typów zadań, jakie realizuje układ rozproszony (jakim jest mózg). Toteż wyniki badań metodą obrazowania mózgu wskazują dokładnie na to, czego powinniśmy spodziewać się po jaźni biologicznej. Po wtóre, jak wiemy, większość funkcji mózgu jest wykonywana bez udziału świadomości; świadome doświadczenie, parafrazując Cricka, stanowi wynik końcowy wielu nieświadomych operacji. ${ }^{9}$ Powinniśmy więc oczekiwać, że jaźń także przeważnie jest nieświadoma. Zatem nasze poczucie jaźni jest po prostu percepcją jaźni i nie należy jej mylić z rzeczywistą jaźnią, tak jak nie powinno się mylić percepcji słonia ze słoniem. W ramach tej biologicznej koncepcji argument Llinása jest zbędny. Nie jesteśmy również niemile zaskoczeni odkryciem, że kolekcja wspomnień epizodycznych nie konstytuuje jaźni. Z biologicznego punktu widzenia żaden z tych problemów nie stanowi problemu.

Taka perspektywa pozwala również na dokonywanie nowych odkryć, podążanie nowymi ścieżkami badań i ustalanie nowych interesujących związków. W dalszej części przytoczymy kilka przykładów. Po pierwsze, w ramach na-

\footnotetext{
${ }^{8}$ Por. Gonzalo MunÉvar, „A Darwinian Account of Self and Free Will”, w: Martin BrinKworth and Friedel Weinert (eds.), Evolution 2.0: Implications of Darwinism in Philosophy and the Social and Natural Sciences, The Frontiers Collection, Springer Verlag, Heidelberg - Dordrecht — London — New York 2012, s. 43-63.

${ }^{9}$ Por. Francis CRICK, Zdumiewająca hipoteza, czyli nauka w poszukiwaniu duszy, przeł. Barbara Chacińska-Abrahamowicz i Michał Abrahamowicz, Na Ścieżkach Nauki, Prószyński i Ska, Warszawa 1997, s. 349-354.
} 
szych najnowszych badań dotyczących przypisywania cech samym sobie, wykonanych metodą funkcjonalnego rezonansu magnetycznego (fMRI) w Harper Hospital na Wayne State University, poprosiliśmy piętnaścioro uczestników i uczestniczek, których badaliśmy za pomocą tomografu o indukcji 3 tesli, o przypisanie sobie, swoim najlepszym przyjaciołom lub znanej osobie (Billowi Gatesowi) szeregu cech osobowościowych i nieosobowościowych. Jak się okazało, w trakcie porównania ja sam-Bill Gates obszarem wykazującym najwyższą aktywność był przedni zakręt kory obręczy [anterior cingulate cortex] (Rys. 1). Był to także najbardziej pobudzony obszar przy odróżnieniu najlepszy przyjaciel-Bill Gates (Rys. 2), aczkolwiek poziom aktywności był znacznie wyższy przy odróżnianiu samego siebie. Ten wynik jest zgodny z ewolucyjnym ujęciem zwierząt społecznych, ponieważ empatia i inne mechanizmy zapewniają nam pewien stopień identyfikacji z tymi, którzy są nam najbliżsi, chociaż nie tak duży jak w wypadku identyfikowania się ze sobą samym. Co jeszcze ciekawsze, przedni zakręt kory obręczy jest anatomicznie zmniejszony u schizofreników, którzy notorycznie nie potrafią odróżnić siebie od innych.
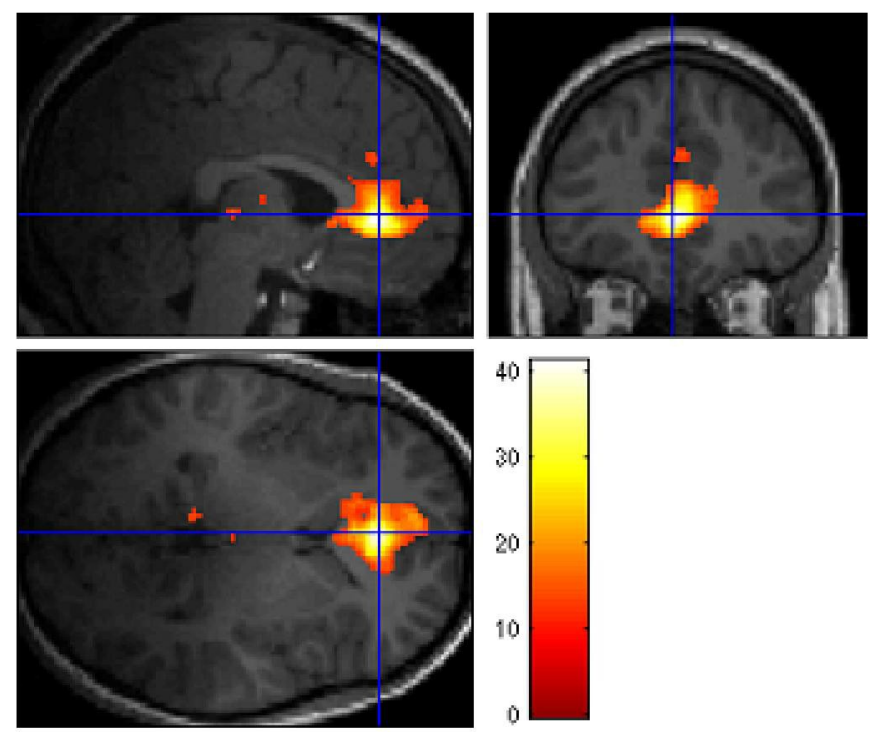

Rys. 1. Przedni zakręt kory obręczy jest wysoce pobudzony $\mathrm{w}$ trakcie zestawienia ja sam-Bill Gates. 

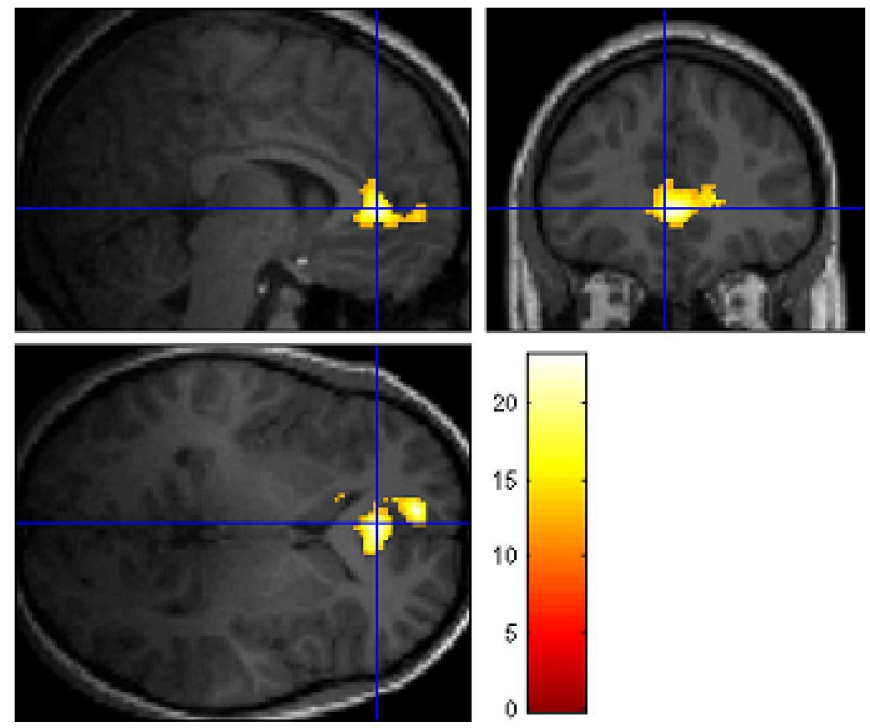

Rys. 2. Przedni zakręt kory obręczy jest pobudzony także w trakcie zestawienia najlepszy przyjaciel-Bill Gates,

chociaż nie tak bardzo jak w trakcie zestawienia ja sam-Bill Gates.

Kolejnym interesującym rezultatem jest to, że wykryliśmy wysokie pobudzenie pola Brodmanna nr 31 [obszaru grzbietowego tylnej części zakrętu obręczy (dorsal posterior cingulate)] podczas rozróżnienia ja sam-najlepszy przyjaciel. Inni badacze stwierdzili, że jest to obszar, w którym mózg uprzedmiotawia swoją orientację przestrzenną, wiążąc ją z punktami orientacyjnymi i innymi cechami otoczenia. ${ }^{10}$ Odkryliśmy również związek z motorycznym układem nagrody w jądrach podstawy [basal ganglia] (wysokie pobudzenie dopaminy wydzielanej w istocie czarnej [substantia nigra]), jakiego można było oczekiwać w świetle poglądu, że mózg wyewoluował do działania. Niewydolność tego układu powoduje chorobę Parkinsona. Mamy także nadzieję, że w toku naszych przyszłych badań (lub przeprowadzonych przez innych badaczy) zostanie usta-

\footnotetext{
${ }^{10}$ Por. Oliver Baumann and Jason B. Mattingley, „Medial Parietal Cortex Encodes Perceived Heading Direction in Humans", The Journal of Neuroscience 2010, vol. 30, no. 39, s. $12897-$ 12901, doi: 10.1523/JNEUROSCI.3077-10.2010.
} 
lony na przykład stopień, w jakim mózgi schizofreników nie są w stanie odróżnić swojego własnego ruchu od ruchów wywołanych przez innych.

Jak widzieliśmy, zastosowanie tradycyjnej koncepcji jaźni w neuronaukach prowadzi do paradoksów, nieporozumień i błędnych wyników. Natomiast biologiczna koncepcja jaźni daje spójniejsze rezultaty i otwiera owocne możliwości badawcze.

Yi Zheng i Gonzalo Munévar

\section{Understanding the Self Biologically}

\section{Summary}

In Total Recall the hero discovers that his good-guy self is just implanted memories. His body used to be occupied by another, vicious self, whose allies want back. This fantasy gains some plausibility from the traditional conception of the self as a collection of experiences kept in memory - a unified conscious self that makes our experiences feel ours. Great fiction, bad neuroscience. There is no central brain structure that corresponds to that self, and some scientists have concluded that the self is an illusion. The notion that the self tags our experiences as ours seems to be wrong. And the idea that the self is a collection of remembered experiences turns out to be false. We propose instead a revolutionary biological conception of the self: The brain has evolved to constitute a self that is mostly unconscious and distributive, which does away with the paradoxes, explains all the seemingly contradictory experimental results, and opens up new avenues of research in neuroscience.

Keywords: self, evolution, neuroscience, distributed brain functions, brain-imaging.

Slowa kluczowe: jaźń, ewolucja, neuronauki, rozproszone funkcje mózgu, obrazowanie mózgu. 